leguminous seeds is more likely to result from colonic fermentation of such unabsorbable sugars as raffinose and stachyose. These are not included in food tables under available carbohydrate and so did not form part of the calculated carbohydrate used in our studies.

In parts of the world where diabetes is less common a substantial proportion of the daily carbohydrate and protein intake may come from leguminous seeds. In India lentils are eaten regularly as dahl together with other leguminous seeds-for example, chick peas-while the soya bean has been cultivated and used for millennia in south-east Asia, China, and Japan. In contrast, in contemporary Western diets wheat as bread, breakfast cereals, pasta, biscuits, pastry, cakes, etc provides the major proportion of the daily starch intake. Nevertheless, this has not always been so, and in the past legumes may have played a much more important part in the European diet, at one time being eaten regularly in Lent, and still being important dietary constituents in southern Italy ${ }^{10}$ and parts of Spain.

A change of diet making use of more leguminous "lentecarbohydrate" sources would allow higher carbohydrate diets to be eaten with relative exclusion of fat. Such changes would probably result in lower fasting serum cholesterol concentrations and smaller rises in postprandial blood glucose values. These changes might help to reduce morbidity and mortality from both diabetes and arterial disease towards levels seen in communities where more slow-release carbohydrates are eaten.

Our results therefore suggested that "slow release" or "lente carbohydrate" in leguminous seeds resulted in flatter blood glucose responses than would otherwise be predicted for a given carbohydrate intake. Further in-vitro studies of digestibility of foods, especially those eaten by communities where diabetes is rare, may provide useful information not only for constructing diabetic diets but to help shape dietary advice in general.
We thank Dr T D R Hockaday, Dr E M Jepson, and Dr S McHardyYoung for permission to study their patients, and the patients for their collaboration and suggestions. The work was supported by the British Diabetic Association and the Medical Research Council.

\section{References}

1 Jenkins DJA, Wolever TMS, Leeds AR, et al. Dietary fibres, fibre analogues, and glucose tolerance: importance of viscosity. $\mathrm{Br} \mathrm{Med} \mathcal{F}$ $1978 ; \mathrm{i}: 1392-4$.

2 Crapo PA, Reaven G, Olefsky J. Postprandial plasma-glucose and -insulin responses to different complex carbohydrates. Diabetes $1977 ; 26: 1178$.

3 Werner W, Rey HG, Wielinger H. Uber die Eigenschaften eines Chromogens für die Blutzuckerbestimmung nach der GOD/POD Methoden. Zeitschrift für analytische Chemie 1970;252:224.

4 Diem K, Lentner L, eds. In: Documenta Geigy: scientific tables. Basle: JR Geigy SA, 1972:712.

${ }^{5}$ Clark LC Jr. A polarographic enzyme electrode for the measurement of oxidase substrates. In: Kessler M, Bruley DF, Leland CC, Lübbers DW, Silver IA, Strauss J, eds. Oxygen supply. Munich: Urban \& Schwarzenberg, 1973:120-8.

6 Paul AA, Southgate DAT. McCance and Widdowson's the composition of foods. 4th ed. Medical Research Council Special Report Series No 297. London: HMSO, 1978.

7 Platt BS. Tables of representative values of foods commonly used in tropical countries. Medical Research Council Special Report Series No 302. London: HMSO, 1962.

8 Silk DBA, Dawson AM. Intestinal absorption of carbohydrate and protein in man. In: Crane RK, ed. Gastrointestinal physiology III. Vol 19. Baltimore: University Park Press, 1979:151-203.

${ }^{\circ}$ Holt S, Heading RC, Carter DC, Prescott LF, Tothill P. Effect of gel fibre on gastric emptying and absorption of glucose and paracetamol. Lancet 1979 ;i :636-9.

10 Trowell HC. Ischaemic heart disease, atheroma and fibrinolysis. In Burkitt DP, Trowell HC, eds. Refined carbohydrate. London: Academic Press, 1975:208.

(Accepted 15 April 1980)

\title{
Smoking habits of men and women
}

\author{
M A H RUSSELL, C WILSON, C TAYLOR, C D BAKER
}

\section{Summary and conclusions}

The smoking habits of 1501 cigarette smokers attending 28 general practitioners in five group practices in London were assessed. Prevalence of smoking, daily cigarette consumption, and the use of cigars, untipped cigarettes, and hand-rolled cigarettes were lower in the women. After controlling for consumption the proportions of men and women who smoked every day were similar. Women who smoked 20 or more a day were similar to men in their self-reported inhaling habits and use of low-nicotine cigarettes.

The results suggest that women differ from men in those aspects of smoking that are determined predominantly by social factors but that their smoking habits become similar when pharmacological motivation takes over. This apparently occurs when consumption reaches about 20 cigarettes a day, when smoking almost inevitably becomes a regular event and the sex differences disappear.

Addiction Research Unit, Institute of Psychiatry, London SE5 8AF M A H RUSSELL, MRCP, MRCPSYCH, senior lecturer

C WILSON, BSC, research worker

C TAYLOR, BSC, statistician

C D BAKER, FRCGP, general practitioner

\section{Introduction}

For several years there has been a steady decline in the prevalence of cigarette smoking in men, but not in women. ${ }^{1}$ Among women smokers there has been a steady increase in daily cigarette consumption, and women have also tended to start smoking at an increasingly early age. Recently there has been concern that they may be less successful than men in giving up smoking. ${ }^{2}$ Our understanding of the differences in smoking habits between men and women is incomplete. This is partly because some of the major surveys-for example, that of McKennell and Thomas ${ }^{3}$-have not focused sufficiently on the sex differences.

During a study of a representative sample of general practitioners' patients ${ }^{4}$ we found the prevalence of cigarette smoking to be $43 \%$ in the men and $34 \%$ in the women (Russell et al and unpublished observations). We now describe the smoking habits of 1501 cigarette smokers in this sample and analyse the similarities and differences between men and women.

\section{Subjects, methods, and results}

All current cigarette smokers aged 16 or more attending the surgeries of 28 general practitioners in five group practices in London during the three weeks from 29 April to 19 May 1974 were asked to complete a questionnaire on smoking. Of the 1666 eligible subjects, 
$1574(94.5 \%)$ gave adequate data, and complete data were available for $1501(90 \cdot 1 \%)$. Details about the general practitioners and the design of the study are reported elsewhere (Russell $e^{t} a^{4}$ and unpublished observations). Statistical significance levels were based on $\chi^{2}{ }_{1}$ tests for linear trend, unless otherwise indicated.

The table shows the smoking habits of men and women, and the figure shows the relation of daily cigarette consumption to some of these habits.

\section{CIGARETTE CONSUMPTION}

The data on daily cigarette consumption were obtained from the question, "When you smoke, about how many cigarettes do you usually smoke in a day ? (under 5, 5-9, 10-14, 15-19, 20-24, 25-29, $30-39,40$ or more)."' The tendency for men to smoke more heavily than women was confirmed, as was the tendency for smokers in the youngest and oldest age groups (especially elderly women) to smoke a little less heavily. The average daily cigarette consumption was 19 for men and 16 for women.

\section{REGULARITY OF SMOKING}

Smokers are usually categorised according to their daily consumption of cigarettes; hence those who do not smoke every day can only estimate an average daily rate. Immediately before the question on amount smoked in a day our subjects were asked, "How often do you usually smoke cigarettes?" Though more women than men were "occasional" smokers (once or twice a week or less) or "irregular" smokers (most days), the difference was not significant, and after controlling for daily consumption there was no sex difference. Among the lighter smokers there was appreciable variation in the regularity of smoking, but once a daily consumption of about one packet (15-24 cigarettes) was reached smoking was a regular event. Age had no effect on the regularity of smoking.

\section{TYPES OF CIGARETTES SMOKED}

Manufactured cigarettes with filter-tips were by far the most popular type used by men and women of all ages, especially younger women. More men than women smoked plain and hand-rolled cigarettes. Use of plain cigarettes was greater in older smokers ( $p<0.001$ in men and women). Use of hand-rolled cigarettes was also greater among older men $(p<0.001)$, but the apparent reverse trend across age in women was not significant. These relations with age were similar when controlled for consumption. There were no significant associations between cigarette consumption and the type of cigarette smoked.

\section{PIPE AND CIGAR SMOKING}

The table shows pipe and cigar use by the cigarette smokers as the percentages of those who responded affirmatively to the question, "Are there some occasions when you enjoy having a cigar or pipe rather than a cigarette ?" ( $46 \%$ of men, $11 \%$ of women). The greater use by men was consistent across all age groups and when cigarette consumption was controlled. There were also trends towards greater use among younger people of both sexes $(p<0.01)$. Though pipe and cigar use among men was greater in the light smokers, this was not significant.

\section{USE OF LOW-TAR, LOW-NICOTINE CIGARETTES}

Current use of low-nicotine cigarettes-Low-nicotine cigarettes $(<0.9 \mathrm{mg})$ were used more by women than by men. Their use was related to cigarette consumption in women $(p<0.05)$ but not in men. Women who smoked 25 or more cigarettes daily seemed as reluctant as men to use them. Age did not affect their use by women, but in men they were used less by younger than by older smokers $(p<0.05)$.

Past experience and perceived ability to change to low-nicotine cigarettes-Past experience of low-nicotine cigarettes and the smoker's perceived ability to change permanently to smoking them were determined by asking, "Have you ever tried smoking 'mild' cigarettes -for example, Silk Cut ?" and "Could you change to smoking 'mild" cigarettes all the time ?" Responses to each question were marked "Yes," "Uncertain," or "No." Few smokers ( $<3 \%)$ expressed uncertainty about having tried mild cigarettes, though almost one in $10(10 \%$ of men, $7 \%$ of women) of those who were actually smoking them did not realise it and reported that they had not tried a mild cigarette. Understandably there were more $(20 \%)$ who were uncertain about their ability to change permanently to mild cigarettes. The women were more likely to have tried milder cigarettes and were also more confident in their ability to change permanently to them. Younger smokers were more likely to have tried them, although they were also less confident in their ability to change to them permanently. All these trends were still evident after controlling for consumption.

The relation of these variables to consumption was complex. Heavier smokers of both sexes were less confident in their ability to change permanently to mild cigarettes $(p<0.001$; see figure). Cigarette consumption, however, had no association with trying mild cigarettes. The apparent tendency among women for lighter smokers to be less likely to try them was not evident after controlling for age and was attributed to the preponderance of older women among the light smokers.

\begin{tabular}{|c|c|c|c|c|c|c|c|c|c|c|c|c|c|c|c|}
\hline & & & & & \multicolumn{8}{|c|}{ Age group (yr) } & \multicolumn{2}{|c|}{ All ages* } & \multirow{3}{*}{$\begin{array}{c}\text { Significance } \\
\text { of difference } \\
\text { between } \\
\text { sexes } \dagger\end{array}$} \\
\hline & & & & & \multicolumn{4}{|c|}{ Men } & \multicolumn{4}{|c|}{ Women } & \multirow{2}{*}{$\underset{(n=584)}{\text { Men }}$} & \multirow{2}{*}{$\begin{array}{c}\text { Women } \\
(\mathbf{n}=982)\end{array}$} & \\
\hline & & & & & $\begin{array}{c}16-24 \\
(n=90)\end{array}$ & $\begin{array}{c}25-34 \\
(\mathrm{n}=103)\end{array}$ & $\begin{array}{c}35-59 \\
(n=241)\end{array}$ & $\begin{array}{c}\geqslant 60 \\
(n=132)\end{array}$ & $\begin{array}{c}16-24 \\
(n=218)\end{array}$ & $\begin{array}{c}25-34 \\
(n=279)\end{array}$ & $\begin{array}{c}35-59 \\
(\mathrm{n}=335)\end{array}$ & $\begin{array}{c}\geqslant 60 \\
(n=103)\end{array}$ & & & \\
\hline \multicolumn{16}{|c|}{ Daily cigarette consumption: } \\
\hline $\begin{array}{l}<5 \\
5-14 \\
15-24 \\
\geqslant 25\end{array}$ & $\begin{array}{l}. . \\
\therefore\end{array}$ & $\begin{array}{l}\ddot{ } \\
\ddot{*}\end{array}$ & $\begin{array}{l}\cdots \\
\because \\
\cdots\end{array}$ & $\begin{array}{l}\cdots \\
\cdots \\
\cdots\end{array}$ & $\begin{array}{l}13.5 \\
33 \cdot 7 \\
36 \cdot 0 \\
16.9\end{array}$ & $\begin{array}{r}5.9 \\
19 \cdot 6 \\
45 \cdot 1 \\
29 \cdot 4\end{array}$ & $\begin{array}{r}9 \cdot 6 \\
22 \cdot 1 \\
45 \cdot 4 \\
22 \cdot 9\end{array}$ & $\begin{array}{r}7 \cdot 6 \\
45 \cdot 5 \\
37 \cdot 1 \\
9 \cdot 8\end{array}$ & $\begin{array}{l}13 \cdot 3 \\
36 \cdot 2 \\
39 \cdot 9 \\
10 \cdot 6\end{array}$ & $\begin{array}{l}15 \cdot 9 \\
31 \cdot 8 \\
36 \cdot 1 \\
16 \cdot 2\end{array}$ & $\begin{array}{l}13 \cdot 2 \\
35 \cdot 3 \\
38 \cdot 0 \\
13 \cdot 5\end{array}$ & $\begin{array}{r}22 \cdot 3 \\
40 \cdot 8 \\
31 \cdot 1 \\
5 \cdot 8\end{array}$ & $\begin{array}{r}8 \cdot 7 \\
28 \cdot 8 \\
41 \cdot 7 \\
20 \cdot 7\end{array}$ & $\begin{array}{l}15 \cdot 6 \\
34.9 \\
36 \cdot 7 \\
12 \cdot 8\end{array}$ & $\begin{array}{l}<0.001 \\
<0.005 \\
\text { NS } \\
<0.001\end{array}$ \\
\hline \multicolumn{16}{|c|}{ Regularity of smoking: } \\
\hline \multicolumn{4}{|c|}{$\begin{array}{l}\text { Regular (every day) } \\
\text { Irregular (most days) } \\
\text { Occasional ( }<3 \text { days a week) }\end{array}$} & $\because$ & $\begin{array}{r}80 \cdot 0 \\
12 \cdot 2 \\
7 \cdot 8\end{array}$ & $\begin{array}{r}86 \cdot 4 \\
8 \cdot 7 \\
4 \cdot 9\end{array}$ & $\begin{array}{r}87 \cdot 9 \\
7 \cdot 5 \\
\quad 4 \cdot 6\end{array}$ & $\begin{array}{r}87 \cdot 8 \\
7.6 \\
4.6\end{array}$ & $\begin{array}{r}77 \cdot 1 \\
16 \cdot 1 \\
6 \cdot 9\end{array}$ & $\begin{array}{r}81 \cdot 4 \\
11.5 \\
7 \cdot 2\end{array}$ & $\begin{array}{r}86 \cdot 2 \\
9.9 \\
3.9\end{array}$ & $\begin{array}{l}78 \cdot 2 \\
10 \cdot 9 \\
10 \cdot 9\end{array}$ & $\begin{array}{r}86 \cdot 6 \\
8 \cdot 4 \\
5 \cdot 0\end{array}$ & $\begin{array}{r}81 \cdot 2 \\
12 \cdot 1 \\
6 \cdot 7\end{array}$ & $\begin{array}{l}\text { NS } \\
\text { NS } \\
\text { NS }\end{array}$ \\
\hline \multicolumn{16}{|c|}{ Type of cigarette: } \\
\hline $\begin{array}{l}\text { Filter } \\
\text { Plain } \\
\text { Hand } \\
\text { Mixec }\end{array}$ & $\begin{array}{l}\text { ped } \\
\text { led } \\
\cdots\end{array}$ & $\begin{array}{l}. \\
\therefore \\
\therefore\end{array}$ & $\begin{array}{l}. \\
\because \\
.\end{array}$ & $\begin{array}{l}\ddot{ } \\
\because \\
\cdots\end{array}$ & $\begin{array}{r}82 \cdot 2 \\
3 \cdot 3 \\
11 \cdot 1 \\
3 \cdot 3\end{array}$ & $\begin{array}{r}72.8 \\
7.8 \\
15.5 \\
3.9\end{array}$ & $\begin{array}{r}59 \cdot 3 \\
14 \cdot 5 \\
24 \cdot 1 \\
2 \cdot 1\end{array}$ & $\begin{array}{r}48.5 \\
18 \cdot 9 \\
31 \cdot 1 \\
1.5\end{array}$ & $\begin{array}{r}93.6 \\
0.5 \\
4.1 \\
1.8\end{array}$ & $\begin{array}{r}93 \cdot 5 \\
2 \cdot 2 \\
3 \cdot 2 \\
1 \cdot 1\end{array}$ & $\begin{array}{r}91 \cdot 0 \\
5 \cdot 1 \\
2 \cdot 7 \\
0.9\end{array}$ & $\begin{array}{r}87 \cdot 4 \\
11 \cdot 7 \\
0.0 \\
1.0\end{array}$ & $\begin{array}{r}62 \cdot 9 \\
12 \cdot 5 \\
22 \cdot 1 \\
2 \cdot 5\end{array}$ & $\begin{array}{r}92.0 \\
3.9 \\
2.9 \\
1.2\end{array}$ & $\begin{array}{l}<0.001 \\
<0.001 \\
<0.001\end{array}$ \\
\hline \multicolumn{16}{|c|}{ Use of low-nicotine cigarettes: } \\
\hline \multicolumn{5}{|c|}{$\begin{array}{l}\text { Usual brand }<0.9 \text { mg } \\
\text { Have tried "mild" brand } \\
\text { Could change to "mild" brand } \ldots\end{array}$} & $\begin{array}{r}3 \cdot 9 \\
74 \cdot 4 \\
29 \cdot 2\end{array}$ & $\begin{array}{r}6 \cdot 1 \\
64 \cdot 1 \\
17 \cdot 8\end{array}$ & $\begin{array}{l}13 \cdot 3 \\
54 \cdot 2 \\
33 \cdot 8\end{array}$ & $\begin{array}{l}10 \cdot 5 \\
46 \cdot 5 \\
39 \cdot 8\end{array}$ & $\begin{array}{l}14 \cdot 9 \\
79 \cdot 4 \\
37 \cdot 7\end{array}$ & $\begin{array}{l}20 \cdot 0 \\
82 \cdot 3 \\
39 \cdot 5\end{array}$ & $\begin{array}{l}18 \cdot 9 \\
67 \cdot 4 \\
47 \cdot 8\end{array}$ & $\begin{array}{l}15 \cdot 2 \\
55.9 \\
60 \cdot 9\end{array}$ & $\begin{array}{l}10 \cdot 0 \\
57 \cdot 2 \\
31 \cdot 7\end{array}$ & $\begin{array}{l}18 \cdot 0 \\
72 \cdot 9 \\
44 \cdot 8\end{array}$ & $\begin{array}{l}<0.001 \\
<0.001 \\
<0.001\end{array}$ \\
\hline \multicolumn{5}{|c|}{ Occasional pipe or cigar use $\quad$. } & $62 \cdot 2$ & $46 \cdot 1$ & $41 \cdot 3$ & $40 \cdot 9$ & $13 \cdot 5$ & $12 \cdot 7$ & $9 \cdot 1$ & $4 \cdot 2$ & $45 \cdot 5$ & $10 \cdot 9$ & $<0.001$ \\
\hline \multicolumn{5}{|c|}{ Inhalation ("a lot" or "fair amount") } & $85 \cdot 6$ & $87 \cdot 4$ & $72 \cdot 7$ & $48 \cdot 8$ & $64 \cdot 5$ & $68 \cdot 4$ & $55 \cdot 4$ & $16 \cdot 5$ & $71 \cdot 8$ & $57 \cdot 3$ & $<0.001$ \\
\hline
\end{tabular}

*Bases for "all ages" are greater than sum of bases for each age category because of missing data on age in some cases.

"Bases for "all ages" are greater than sum of bases for each age category because of missing data on age in some cases.
+ Derived after controlling for age using $\chi^{2}$, test. Values were similar after controlling for consumption and for both age and consumption where appropriate. NS $=$ Not significant. 


\section{INHALATION}

Our measure of inhalation was identical with that in the Tobacco Research Council surveys except that we included a "don't-know" category. ${ }^{5}$ This included $1.6 \%$ of men and $6.3 \%$ of women $(p<0.001)$. The proportions who reported inhaling "a lot" or a "fair amount" were similar to the Tobacco Research Council's findings. Women reported inhaling less than the men, but among those who smoked 15 or more cigarettes daily the amount of inhalation reported was similar to men (figure). There were fewer inhalers among older smokers, especially in women. This was still evident after controlling for consumption ( $\mathrm{p}<0.001$ for men and women).

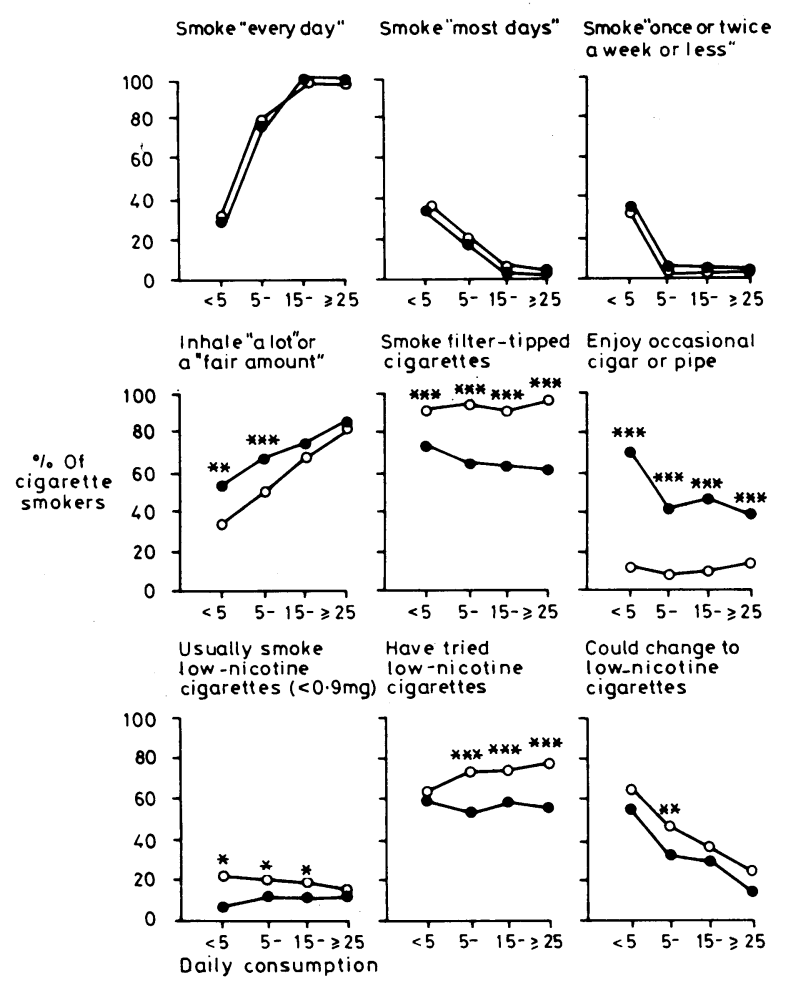

Relation of daily. cigarette consumption to some smoking habits in men (O) and women (O). $\chi^{2}{ }_{1}$ test: ${ }^{*} \mathrm{p}<0.05 ;{ }^{* *} \mathrm{p}<0.01$; $* * * \mathrm{p}<0.001$

\section{Discussion}

In some respects the smoking habits of women differ greatly from those of men, whereas in others they are closely similar. We suggest that men and women differ in those components of their smoking habits that are determined predominantly by social factors but are similar in components determined mainly by pharmacological factors. This hypothesis seems compatible with most of the data. There is little doubt that taking up smoking depends mainly on social factors. ${ }^{6}$ Thus men and women differ greatly in the prevalence of smoking. ${ }^{5}$ This difference, however, has narrowed substantially over the years as women smoking has become socially more acceptable. Indeed, in 1971 for the first time the prevalence of smoking among 16-year-old girls was the same as among boys $(36 \%){ }^{7}$ Recruitment to smoking occurs mainly during youth, suggesting that social attitudes to it have more influence on young people. Elderly women, for example, may still largely be guided by the mores that prevailed when they were young and "susceptible," so that it may be some time before the changes in attitudes become apparent in all age groups. The data for 16-year-olds, however, suggest that the prevalence of smoking among women will eventually reach or exceed that in men.

Other ways in which men and women differ noticeably are in the nature of the products smoked. Thus women hardly ever smoke cigars, very few of them use hand-rolled cigarettes, and they are less likely than men to use untipped cigarettes. There is no evidence of a biological difference between the sexes in their reaction to the stronger and more irritant taste of these products, and the differences, like prevalence, are probably socially determined. This is supported by their strong relation to age. Social attitudes determining these differences may be formed to some extent by advertising. The greater use of cigars among the younger age groups of both sexes may, for example, reflect their greater sensitivity at the time their smoking habits were being formed to the heavy promotion of cigars on television since the ban, in 1965, on cigarette advertising. The fact that use of these products had no significant relation to cigarette consumption suggested that their use was not determined by pharmacological factors.

The variable that showed the most striking similarity between men and women was the regularity of smoking after controlling for consumption. In this respect men and women were virtually identical. The regularity of smoking was strongly related to daily cigarette consumption, which suggests that it may be related to pharmacological factors or the degree of dependence, or both. The data suggest that a critical value is reached at about 20 cigarettes daily and that it is virtually inevitable that smoking then becomes a regular event, possibly because pharmacological factors then take over.

Inhalation was also strongly related to daily cigarette consumption, suggesting that it is determined pharmacologically. Among light smokers women are less likely to inhale, but once the critical level of about one packet a day is reached they inhale as much as men. This is the same critical level as for the virtual inevitability of regular smoking. If this is indeed the level at which pharmacological factors also take over as the main determinants of smoking the hypothesis that the smoking habits of men and women become similar at the point when pharmacological motivation predominates is supported. This explanation of the data on inhalation and the hypothesis would be supported by finding that blood nicotine concentrations in women are lower than in men in the case of light smokers but similar at a daily consumption of 20 or more. Such a study is being undertaken. Women who were light smokers, and therefore not pharmacologically motivated, inhaled less than men, possibly because of $(a)$ a lower tolerance to strong irritants, $(b)$ some unknown social factor affecting inhalation, or $(c)$ a sex difference in validity of self-reported inhalation.

Though many smokers had tried mild cigarettes $(57 \%$ of men, $73 \%$ of women), few were actually smoking them $(10 \%$ of men, $18 \%$ of women). Confidence in the ability to change permanently to mild cigarettes was strongly related to daily cigarette consumption, suggesting the action of pharmacological factors. The lack of a sex difference in this respect among heavier smokers is in keeping with the above hypothesis. Initially it may seem surprising that regular use of low-nicotine cigarettes was not related to daily consumption, but a tendency to increase consumption after switching to low-nicotine cigarettes may have masked such a relation.

Although no data on giving up smoking are presented here, this is another aspect in which sex differences are sometimes believed to occur. Cessation rates are often cited by referring to the simple percentage of ex-smokers in the population. This is misleading. A more realistic index of giving up is obtained by basing the proportion of ex-smokers only on those who have "ever smoked"-that is, current smokers and ex-smokers combined-and not on the whole population. For example, according to the Tobacco Research Council's data on the general population in 1974 the proportion of smokers who had stopped was $23 \%$ and $21 \%$ for men and women respectively, whereas the simple proportions of ex-smokers in the population were $16 \%$ and $11.5 \%$ respectively. ${ }^{6}$ Thus it is apparent that cessation rates in men and women smokers in the population are similar when appropriate indices are used. Men and women may be similar in this respect because once the habit is established pharmacological factors predominate irrespective of the smoker's sex.

The validity of self-reported smoking habits is always suspect. 
We have no reason, however, to suspect that there was any sex difference in this respect, so that our comparisons between men and women were unlikely to have been seriously affected by this source of error.

The fact that $32 \%$ of the men and $45 \%$ of the women smokers thought that they could change permanently to a low-nicotine brand suggests real scope for health educationists in encouraging them to do so.

We thank the following general practitioners for co-ordinating their partners and allowing us to study their patients: Dr I F Crabbe, Dr Elisabeth Horder, Dr M A Newland, and Dr R H Burton. We also thank R Iyer for statistical help and Jean Crutch for secretarial work. Our colleagues J R Eiser, $M$ Jarvis, $M$ Raw, and S R Sutton gave useful advice during the analysis and write-up. Financial support was provided by the Department of Health and Social Security and the Medical Research Council.

\section{References}

1 Cappell PJ. Trends in cigarette smoking in the United Kingdom. Health Trends 1978;10:49-54.

2 Gritz ER. Women and smoking: a realistic appraisal. In: Schwartz JL, ed. Progress in smoking cessation. New York: American Cancer Society, 1978:119-41.

${ }^{3}$ McKennell AC, Thomas RK. Government Social Survey. Adults' and adolescents' smoking habits and attitudes. London: HMSO, 1967.

4 Russell MAH, Wilson C, Taylor C, Baker CD. Effect of general practitioners' advice against smoking. $B r$ Med $\mathcal{F} 1979$;ii:231-5.

5 Lee PN. Research Paper 1. Statistics of smoking in the United Kingdom. 7th ed. London: Tobacco Research Council, 1976.

${ }^{6}$ Russell MAH. Cigarette smoking: natural history of a dependence disorder. Br f Med Psychol 1971;41:1-16.

7 Todd GF. Research Paper 1. Statistics of smoking in the United Kingdom. 6th ed. London: Tobacco Research Council, 1972.

(Accepted 2 April 1980)

\title{
Intermittent treatment of duodenal ulcer with cimetidine
}

\author{
KARNA DEV BARDHAN
}

\section{Summary and conclusions}

Intermittent treatment with short courses of cimetidine given only when symptoms recurred was assessed in patients with duodenal ulcer as an alternative to maintenance treatment. Their progress was followed up for up to 22 months. Gastroscopy was carried out in most attacks to confirm recurrence of the ulcer and subsequent healing. Out of 125 patients treated, 83 relapsed, of whom 21 defaulted. After retreatment 36 patients relapsed again. The pattern of relapse and remission for the group as a whole was similar after both courses of treatment, indicating an unchanged natural history. Nevertheless, wide variation occurred in individual patients, so that the pattern of relapse could not be predicted by the duration of the initial remission.

Most patients had one or two or rarely three symptomatic relapses a year, which were rapidly treated successfully with cimetidine. Therefore, unless the necessity for long-term maintenance treatment is established, intermittent treatment provides an adequate alternative in most patients with duodenal ulcer.

\section{Introduction}

After initial treatment with cimetidine to heal duodenal ulcer maintenance treatment at a lower dose is often recommended to prevent recurrence. Though the treatment is generally effective, no data are available on the results beyond a year. ${ }^{2}$ Several unanswered questions remain: Is such treatment effective over longer periods? Do all patients require it, and if not how should patients be selected ? How long should treatment be continued ? Will it remain safe? Because these questions have not been answered I have used an alternative method of treatmentnamely, giving cimetidine only when troublesome symptoms

District General Hospital, Rotherham S60 2UD

KARNA DEV BARDHAN, DPHIL, MRCP, consultant physician recur. Though this method is commonly used in hospitals and general practice, its outcome has not been assessed. I therefore report here on the use of intermittent treatment in 125 patients.

\section{Patients and methods}

Patients with duodenal ulcer were treated with cimetidine $1 \mathrm{~g}$ daily until the ulcer had healed; ulceration and healing were confirmed by endoscopy. The drug was then stopped. If minor symptoms such as slight heartburn or upper abdominal discomfort continued or recurred the patients were advised to use small amounts of antacids. If, however, their symptoms became troublesome they came back to see me and after assessment received a second course of cimetidine. This was repeated for a third time if a further relapse occurred. In most patients cimetidine for one to two months produced healing. During most relapses endoscopy was repeated to confirm both ulceration and healing before the cimetidine was begun again and stopped. In 10 episodes, however, this was not possible. These patients are nevertheless included for analysis because they had a recurrence of typical symptoms that almost invariably indicated reulceration. ${ }^{3}$

The patients' progress was followed up for up to 22 months, after which time those who had not recently had a relapse were recalled for interview. The pattern of relapse and remission was examined. The remission period was arbitrarily taken to be the period when the patients were not taking cimetidine.

\section{Results}

One hundred and twenty-five patients were treated until the ulcer healed. During the next 22 months 83 patients relapsed (fig 1). After six months 48 patients $(38 \%)$ had relapsed including five $(4 \%)$ in less than one month, but 53 patients $(42 \%)$ were in clinical remission for over one year. Of the patients who relapsed, 21 defaulted. The remaining 62 patients were retreated, but 36 relapsed again. Of these, $29(47 \%)$ had relapsed by six months including five $(8 \%)$ in less than one month, but $29(47 \%)$ were asymptomatic for over a year (fig 2). The pattern of the second relapse was similar to that of the first.

From these data the probability that a patient would remain in remission after treatment with cimetidine was calculated by lifetime analysis (fig 3). The results after one and two short courses of cimetidine are similar, indicating that the natural history of the disease is unchanged. Figure 3 also shows that the chances of staying 